\title{
PAST HISTORY AND DEGREE OF DEPRESSION IN PARAPLEGIC INDIVIDUALS
}

\author{
Vivienne KatZ, M.S., ${ }^{1}$ Robert Gordon, M.A., ${ }^{2}$ David Iversen, M.D. ${ }^{1}$ \\ and STANLEY J. MYers, M.D ${ }^{1}$ \\ 1 Department of Rehabilitation Medicine, Columbia-Presbyterian Medical Center; \\ ${ }^{2}$ Columbia University Rehabilitation Counseling Program
}

Abstract. The purpose of this study was to attempt to collect sufficient data to substantiate the clinical impression that the degree of depression in the paraplegic and his past history are correlated. It was hypothesised that the poorer the past history, the greater the degree of depression in paraplegic individuals.

This study was conducted on ten paraplegic subjects from the Spinal Cord Clinic at Columbia Presbyterian Medical Center, Department of Rehabilitation Medicine, based on data obtained from the administration and scoring of the Depression Scale (D-scale) of the Minnesota Multiphasic Personality Inventory (MMPI) and by the clinical observation by the consulting psychiatrist with the Spinal Injury Clinic. Past history was assumed measurable as 'favourable' to 'poor' by the use of an original questionnaire.

The results of this investigation suggested a relationship between a paraplegic individual's past history and the degree of depression. The study was deemed significant in presentation of an original past history questionnaire and in the prediction of future difficulties in the rehabilitation of paraplegics so that preventive measures could be instituted.

Key words: Depression in paraplegics.

\section{Introduction}

IT has been observed that an important factor influencing the results of the rehabilitation process in the paraplegic patient is the degree of depression, and that there appears to be a strong relationship between the extent of depression and the past history; i.e., the more unsettled the past history, the greater the degree of depression during the illness.

The purpose of this study was, therefore, to attempt to collect sufficient data to substantiate the clinical impression that the degree of depression in the paraplegic and his past history are correlated. In this investigation it was assumed that factors other than 'good' or 'poor' past history come into play, influencing the rehabilitation outcome; these include: (I) age of onset; (2) prior educational and vocational plans; (3) aetiology and prior medical history; (4) neurological level of lesion; (5) presence and severity of medical complications of the illness and its treatment; (6) past physical prowess; (7) family and personal support; (8) state of mind of the paraplegic patient. In reviewing the factors recorded above, it is evident that each alone plays an important role in the success or failure of the rehabilitation process; however, each factor in turn is related to the other. The mental status of the individual and the degree of depression are interrelated in direct proportion, i.e., a healthy mental outlook presupposes little or no chronic depression. Similarly, it can be assumed that the younger, stronger, more athletic paraplegic patient with a lower level of lesion or incomplete motor lesion will more easily achieve wheelchair independence and even ambulation with bracing (Myers 
1974a). The aetiology of the paralysis is often 'a very important factor in determining the patient's psychological reactions to the disability' (Myers, 1974 $\bar{b}$ ). Harris et al. (I973a) say, 'thus regarding trauma it was important to know if the trauma occurred at work or, for example, as the result of an accident or while participating in sports'. In addition, they say, 'a knowledge of past medical history of patient and family regarding psychological disturbances can help to foretell the immediate reaction to an acute spinal paralysis (Harris et al., I973b).

Sir Ludwig Guttmann (1973a) summarised this concept by saying: 'In the establishment of the psychological pattern in paraplegics and tetraplegics, the pre-traumatic personality, general mental ability, educational background, social standing, profession, age as well as the severity and duration of the paralysis and the type and efficiency of the initial treatment following injury, were found to be essential factors'.

It must also be assumed that depression can be defined and measured and that past history can be evaluated with accuracy. According to Tregold (1953), emotional depression is defined as natural to painful mental experiences and to many disturbances of physical health, tending to produce a slowing of thought and a lessening of motor activity. Depression may bring about retardation of thought, general apathy, diminished activiiy and gloom. The onset may be marked by sleeplessness and loss of interest. Another definition of depression is that of Bibring (1953), which characterises depression as a state of helplessness of the ego which results from tension in the ego between narcissistic aspirations and its helplessness to achieve them. Thus depression is the emotional correlate of a partial or complete collapse of the self-esteem of the ego, since it feels unable to live up to its aspirations (ego ideal) (Eidelberg, I968). These formulations of depression are not as elaborate or abstract as some of the early psychoanalytical theories but can be more easily correlated with clinical material. In this study, depression is defined as a 'state of mind' which is characterised by a decreased interest in the external world and an increase of aggression against the self; self-criticism, feelings of guilt, remorse and self-punishment, which are precipitated by an object loss (i.e., paralysis of the legs and the lower part of the body) (Bibring, I953). Generally, 'more serious are those patients who develop depression, resulting in all kinds of physical complaints including pain which may become an irrevocable fixation (Guttmann, I973b).

\section{Methods}

The evaluation of the extent of the depression in the ten paraplegic subjects selected for this investigation was based on data obtained from the administration and scoring of the Depression Scale (D-scale) of the Minnesota Multiphasic Personality Inventory (MMPI) and by the clinical observations of one of us (D. I.) acting as a psychiatrist with the Spinal Cord Injury Clinic.

The personality inventory (MMPI) was developed by Hathaway and McKinley (I940) at the University of Minnesota as a clinical instrument for use in psychiatric diagnosis (Super \& Crites, I967a). Their purpose was to develop one personality inventory which would measure those aspects of personality which bear on psychiatric diagnosis. They wished to make more objective the judgements that are reached in a clinical situation by providing more systematic coverage of behaviour and attitude items than is generally possible in an interview (Super \& Crites, 1967b). The depression scale is measuring 'symptomatic depression'. The term 'symptomatic' is used in order to limit the identification of the term 'depression' with the presence at the time of testing of a clinically recognisable, 
general frame of mind characterised by poor morale, lack of hope in the future and the patient's own dissatisfaction with his status. Such a clinical picture might result from economic or vocational frustration, from personal problems, from a depressed stage of a cycloid personality, or from any one of the other known clinical backgrounds of depression. We, therefore, are assuming a multi-faceted view of depression and that both conscious awareness and underlying chronic depression can be measured through testing (Hathaway, I956).

Each of the ten paraplegic patients in this group were seen in individual sessions with the psychiatrist (D. I.) who measured the degree of depression, both by interviews and observations and the presence of the vegetative signs of depression, namely: $(a)$ insomnia; $(b)$ anorexia; $(c)$ general fatigue; $(d)$ crying spells; $(e)$ sexual interest; $(f)$ suicidal ideation; $(g)$ self-destructive tendencies; and $(h)$ affect (Beck, 1967). He divided the group into three categories: (I) not depressed; (2) moderately depressed to depressed; and (3) severely depressed.

The assumption that past history could be measured was approached by the use of an original questionnaire based on the ingredients of personality development which help to formulate one's self-concept and self-image. It is felt that there is no one type of personality structure which accompanies a paraplegic patient and that what we observed in the paraplegic patient is an exaggeration of the problems which are common to many non-disabled persons. A favourable past history included the following criteria: (a) early nurturing by the mother with both parents present in the home; $(b)$ an expressed remembrance by the patient of early, positive, warm feelings toward parents and siblings; $(c)$ a work-oriented family in early childhood as opposed to welfare recipients; $(d)$ at the time of the patient's accident, evidence of acceptable living standards such as middle income or better socioeconomic level; $(e)$ realistic expectations of family for patient; $(f)$ if married, stated acceptable quality of marriage; $(g)$ educational achievements commensurate with ability; $(h)$ history of upward mobility in school or work; $(i)$ expressed good interpersonal relations with fellow students and fellow workers; and $(j)$ expressed satisfaction with social life at the time of the accident.

The MMPI and questionnaire were administered individually to each subject and each person was interviewed usually on the same day.

\section{Results}

The results of the testing and interview suggest a relationship between a paraplegic individual's past history and degree of depression. Table I shows that the patient with a low score on the Past History Questionnaire, which was indicative of 'poor' past history, achieved a high score on the D-scale of the MMPI, which indicated a 'high' level of depressive state. In addition, Table I reveals the trend or scatter of the questionnaire scores toward a direct correlation between 'favourable' past history and decreased depression. The highest score obtainable on the Past History Questionnaire was 20. The scores on the MMPI in this group of subjects ranged from a low score (least depressed) of 27 to the highest score of 50 (most depressed). The scatter on the Past History Questionnaire grouped around a norm of $16 \cdot 2$; the scatter on the MMPI averaged out to a norm of $36 \cdot 2$ for this group.

Table I also presents a rank order on the three measurements (Past History Questionnaire, MMPI, and Clinical Observation) of the ten subjects used in this study. It is followed by the Spearman Rank Order Coefficient indicating a positive correlation between the three measurements, i.e., the higher the past 
TABLE I

\begin{tabular}{|c|c|c|c|c|c|c|}
\hline \multirow[t]{2}{*}{$\begin{array}{l}\text { Subject } \\
\text { no. }\end{array}$} & \multicolumn{2}{|c|}{$\begin{array}{c}\text { Past history } \\
\text { questionnaire }\end{array}$} & \multicolumn{2}{|c|}{ MMPI scores } & \multicolumn{2}{|c|}{$\begin{array}{c}\text { Psychiatric } \\
\text { clinical observation }\end{array}$} \\
\hline & Score & $\overline{R a n k}$ & Score & Rank & Score & Rank \\
\hline I & I9 & $I \cdot 5$ & 32 & 3 & Not depressed & $I \cdot 5$ \\
\hline 2 & I9 & $I \cdot 5$ & 27 & I & Not depressed & $1 \cdot 5$ \\
\hline 3 & I8 & 3 & 36 & 6 & $\begin{array}{l}\text { Moderately } \\
\text { depressed }\end{array}$ & $5 \cdot 5$ \\
\hline 4 & I7 & 5 & 34 & 4 & $\begin{array}{l}\text { Moderately } \\
\text { depressed }\end{array}$ & $5 \cdot 5$ \\
\hline 5 & I7 & 5 & 36 & 6 & Depressed & $5 \cdot 5$ \\
\hline 6 & I7 & 5 & 36 & 6 & $\begin{array}{l}\text { Moderately } \\
\text { depressed }\end{array}$ & $5 \cdot 5$ \\
\hline 7 & I6 & 7 & 38 & 8 & Depressed & $5 \cdot 5$ \\
\hline 8 & I4 & 8 & $3 \mathrm{I}$ & 2 & Depressed & $5 \cdot 5$ \\
\hline 9 & I3 & IO & 42 & 9 & $\begin{array}{l}\text { Severely } \\
\text { depressed }\end{array}$ & $9 \cdot 5$ \\
\hline \multirow[t]{2}{*}{ IO } & I 2 & 9 & 50 & IO & $\begin{array}{l}\text { Severely } \\
\text { depressed }\end{array}$ & $9 \cdot 5$ \\
\hline & \multicolumn{2}{|c|}{$\begin{array}{c}\text { (Maximum score }=20 \text {; } \\
\text { highest score-'most } \\
\text { favourable' and highest } \\
\text { ranked) }\end{array}$} & \multicolumn{2}{|c|}{$\begin{array}{l}\text { (Lowest score; } \\
\text { 'least depressed' } \\
\text { and highest ranked) }\end{array}$} & \multicolumn{2}{|c|}{$\begin{array}{l}\text { (Highest ranked; } \\
\text { i.e. no. I, 'least } \\
\text { depressed') }\end{array}$} \\
\hline
\end{tabular}

history score (closer to a maximum of 20), the lower the MMPI score and level of depression on clinical observation.

When comparing the four highest scores (I7-I9) with the three lowest scores (I2-I6) on the Past History Questionnaire, it was found that in the low-scoring group: (I) all had vocational and educational instability; (2) two had family histories showing restrictions and physical punishment, little parental praise; and (3) at the time of their injury, both of these individuals did not have a close relationship with a member of the opposite sex. In contrast, those individuals with the 'most favourable' past history as a group had the following results: (I) all had family histories showing praise for good behaviour, non-authoritarian atmospheres; (2) three had histories without parental physical punishment; (3) only one showed a history of vocational and educational instability; (4) at the time of their injury, three of the four expressed a closeness with a member of the opposite sex (wife or girl friend); (5) while two of the low-scoring group had fathers with poor educational background (8th grade or less), not one member of the high-scoring group had fathers who did not at least attend high school.

\section{Case Reports}

Two representative case histories are presented.

Case I. Male paraplegic, age 2 I years, is the youngest of five children. His father worked as a baker, then as a truck driver. When he was I I years of age, 
his parents separated and his mother began drinking heavily. While in junior high school he left home to live for a brief period with his older married brother and upon return to New York to again live with his mother, whose drinking had become serious. He did not return to high school but began part-time work as a finishing repairman and a truck driver, and during this time he fathered a child. He began to use drugs until his father enrolled him in a drug treatment centre. Although he initially agreed to the treatment, he later resisted the system for the 4 months he spent at the centre. In September 1972, while out of the drug rehabilitation centre on a week-end pass, he fell out of a three-storey window in his father's apartment, sustaining a permanent paraplegia with motor and sensory level at $\mathrm{T} 2$.

After his initial hospital confinement, he was transferred to a rehabilitation centre for a complete rehabilitation programme. Vocational planning steered him toward a long period of higher education in college after he had achieved a High School Equivalency Diploma. He lived in a dormitory on campus and went to school under the auspices of the Office of Vocational Rehabilitation. At college, he neglected his physical care, did poorly in schoolwork, and developed decubitus ulcers for which he had to be hospitalised for a prolonged period of over I year.

$\mathrm{He}$ is presently back with his mother whose problems have not been resolved. A new referral to the Office of Vocational Rehabilitation has been instituted in another attempt at vocational rehabilitation.

The present testing results on this patient reflected a 'poor' past history with chronic underlying depression and self-destructive tendencies, which were more obvious during the clinical observation and interview by the psychiatrist. His relatively low score on the MMPI might be attributed to the high ' $L$ ' (Lie) factor involved in his responses.

Case 2. Male paraplegic, age 23 years. He had been followed at ColumbiaPresbyterian Medical Center since he was 3 years old because of a spinal cord tumour which was partially removed at that time. Since the age of I3 years, he has been completely paraplegic with sensory and motor level at Ti2. He was taught to use bilateral, long leg braces with Knight spinal attachment, but had not made use of them. He is independent in all activities of daily living.

This patient has a stable family life with supportive, caring parents, and lives with them and two older siblings, initially in a five-room elevator apartment in the Bronx. They later moved to Long Island near the university which the patient attended. His father owned and operated his own business and has continued to be sole supporter of the family. Up to the 8th grade, he attended a Catholic parochial school with average academic achievements. After the onset of paraplegia he attended special health classes in the local public school. He was transported by school bus. In local high school he attended regular classes but still was transported by bus. He graduated in 1970 and was referred to the Office of Vocational Rehabilitation (OVR) for services and financial support toward higher education. He applied and was accepted into a university in September 1970 for a degree in Business Administration, Accounting and I.B.M. Computer Training. He lived on campus under OVR auspices and managed well academically and socially. He graduated June I974 and continued on with graduate courses at the same university and lives on campus. He expects to qualify for his Certified Public Accountant examination. He drives the family car with hand controls.

This patient had an excellent adjustment to his disability and has achieved in school. He scored high (I9) on the 'Past History Questionnaire', and low both on the degree of depression on the MMPI and clinical psychiatric consultation. 


\section{SUMMARY}

This is a preliminary report investigating the relationships between the degree of depression and past social, educational and vocational background in a sample of ten paraplegic male patients from the Spinal Cord Clinic at ColumbiaPresbyterian Medical Center. Evidence has been presented to substantiate the clinical observation that paraplegics with 'favourable past histories' tend to be less depressed.

Four factors included in the Past History Questionnaires: (I) too many restrictions in early environment; (2) painful punishment or threats thereof in early childhood; (3) vocational and educational instability; and (4) feelings of rejection by wife or girl friend at the time of injury seem to be present with more frequency in the severely depressed group.

The significance of this study is to enable workers to predict future difficulties in the rehabilitation of paraplegics whose past histories are 'poor', so that preventive measures such as early psychiatric intervention, early realistic vocational planning, and possibly early medication for alleviation of depression can be instituted.

It is felt that the original Past History Questionnaire might be a useful tool for both psychiatrists and vocational counsellors in their evaluations.

A broader study is recommended with a larger and more random population of paraplegic subjects.

\section{RÉSUMÉ}

Cette étude est un réport preliminaire qui réchèrche les rapports êntre le degré de la melancolie et de l'histoire passée sociale, éducationelle et professionelle dans une groupe de dix hommes paraplegiques de la Clinique de la Corde Epine a Columbia-Presbyterian Centre Medical. L'evidence était présente pour substantier l'observation clinical que les paraplegiques avec 'des histoires favorables' ont moins de d'etre melancoliques.

Quatre indications incluses dans le questionnaire passé sont: (I) trôp de contraintes au debut dans leur environs; (2) des punitions pénibles ou de ménaces dîtes dans leur enfance; (3) l'instabilité professionelle, educationelle; et (4) des sentiments de réjection par une femme ou une amie qui aù moment de l'accident semblent être présents plus souvent dans la groupe très mélancolique.

La significance de cette étude est de faciliter les employers a prédire les difficultés futures dans la réhabilitation des paraplêgiques dont les histoires sont faibles pour que au début des mesurs préventifs, par example d'intervention psychiatrique, de la conduite professionelle realistique et peut-être de médication pour diminuer la mélancolie sera introduit.

On sent que la questionnaire passée peutêtre utile pour les psychiatres etdes conseilleurs professionels dans leur évaluations.

Une étude plus profonde est recommendé dans une groupe plus grande de paraplegiques et moins sélective.

\section{ZUSAMMENFASSUNG}

Diese Studie ist der Einleitungspunkt für die Erforschung des Verhältnisses zwischen dem Ausmass von Depression und früheren sozialen, Erziehungs und beruflichen Hintergründen, von Io paraplegischen Männern in der Spinal Cord Clinik im Columbia Presbyterian Medical Center. Sie bestätigt die klinischen Beobachtungen, dass Paraplegiker mit 'guten Vorgeschichten' weniger deprimiert sind.

Vier Faktoren sind inbegriffen in der Vorgeschichte: (I) zu viele Einschränkungen in der Kindheit; (2) schmerzhafte Bestrafungen oder Drohungen in der Kindheit; (3) Beschäftigung oder Schulung Instabilität; und (4) Gefühle von Verwerfung von Freundinnen oder Gemahlinen zur Zeit der Verletzung scheinen öfter bei der schwer depressiven Gruppe zu sein.

Diese Studie soll behilflich sein, um zukünftige Schwierigkeiten bei der Wiederherstellung von Paraplegiker voranszusagen, die eine 'traurige' Vorgeschichte haben, so dass 
Vorkehrungen getroffen werden können, wie zum Beispiel psychiatrische Behandlungen, frühe Geschäftsvorbeitungen und möglicherweise auch Medikamente, um diese Depressionen $\mathrm{zu}$ vermeiden.

Wir sind der Ansicht, dass der originale Fragebogen über die Vorgeschichte für Psychiater und Berater behilflich sein wird.

Es wird empfohlen, dass eine grössere Studie über den paraplegischen Patienten gemacht wird.

\section{REFERENCES}

Beck, A. (1967). Depression: Clinical, Experimental, and Theoretical Aspects. Harper and Row, New York. p. 176.

Bibring, E., in Greenacre, P., ed. (1953). Affective Disorders. The mechanism of depression. Int. Univ. Press, New York, pp I3-48.

EIDELBERG, L. (1968). Encyclopedia of Psychoanalysis. Collier-Macmillan Limited, New York, p. $4 \mathrm{I} 6$.

Guttmann, L. (1973a). Spinal Cord Injuries, Comprehensive Management and Research. Blackwell Scientific Publications Ltd, Osney Mead, Oxford, p. 478.

Guttmann, L. (1973b). Spinal Cord Injuries, Comprehensive Management and Research. Blackwell Scientific Publications Ltd, Osney Mead, Oxford, p. 48I.

Harris, P., Patel, S. S., Greer, W. \& Noughton, J. A. (I973a). Psychological and social reaction to acute spinal paralysis. Int. F. Paraplegia, II, I32.

Harris, P., Patel, S. S., Greer, W. \& Noughton, J. A. (I973b). Psychological and social reaction to acute spinal paralysis. Int. F. Paraplegia. II, I34.

Hathaway, S. R. \& McKinley, J. C. (1956). Basic Readings of the MMPI in Psychology and Medicine. U. of Minnesota Press, Minnesota, p. 73.

Myers, S. J., in Downey \& Low, ed. (1974a). The Child With Disabling Illness. Chapter 6, 'The spinal cord injury patient'. W. B. Saunders Co., Philadelphia, p. I I7.

Myers, S. J., in Downey \& Low, ed. (1974b). The Child With Disabling Illness. Chapter 6, 'The spinal cord injury patient'. W. B. Saunders Co., Philadelphia, p. I20.

Super, D. E. \& CRITES, J. O. (1967a). Appraising Vocational Fitness. Harper \& Row, New York, p. 520.

Super, D. E. \& CRITES, J. O. (1967b). Appraising Vocational Fitness. Harper \& Row, New York, p. $52 \mathrm{I}$.

Tregold, R. F. (1953). Manual of Psychological Medicine. Williams \& Wilkins, London, 3rd ed., p. I 19 . 